\title{
The Eph Receptor/Ephrin System: An Emerging Player in the Invasion Game
}

\author{
Tessa N. Campbell and Stephen M. Robbins \\ Southern Alberta Cancer Research Institute, \\ Departments of Oncology and Biochemistry \& Molecular \\ Biology, University of Calgary, Calgary, AB
}

\begin{abstract}
Eph receptor tyrosine kinases (Ephs) and their membrane-anchored ligands (ephrins) form a vital cell communication system capable of bi-directional signaling. This Eph receptor/ephrin system has classically been demonstrated to play a role in development. However, emerging evidence has revealed differential expression of Ephs and ephrins in numerous cancers. Recent studies suggest that this system influences invasive behaviour, promoting a more aggressive and metastatic phenotype. Hence, this minireview summarizes the current understanding of the contribution of both Eph receptors and their ephrin ligands to invasiveness in cancer, as well as their use as potential therapeutic targets.
\end{abstract}

\section{Eph Receptor/ Ephrin Signaling}

Eph receptors (erythropoietin-producing human hepatocellular carcinoma) comprise the largest family of vertebrate receptor tyrosine kinases. In concert with their ephrin ligands (Eph family receptor interacting proteins), they form an essential cell-cell communication system capable of bi-directional signaling, where receptor signaling is designated "forward" and ephrin signaling is "reverse" (Fig.1; Kullander and Klein, 2002; Heroult et. al., 2006).

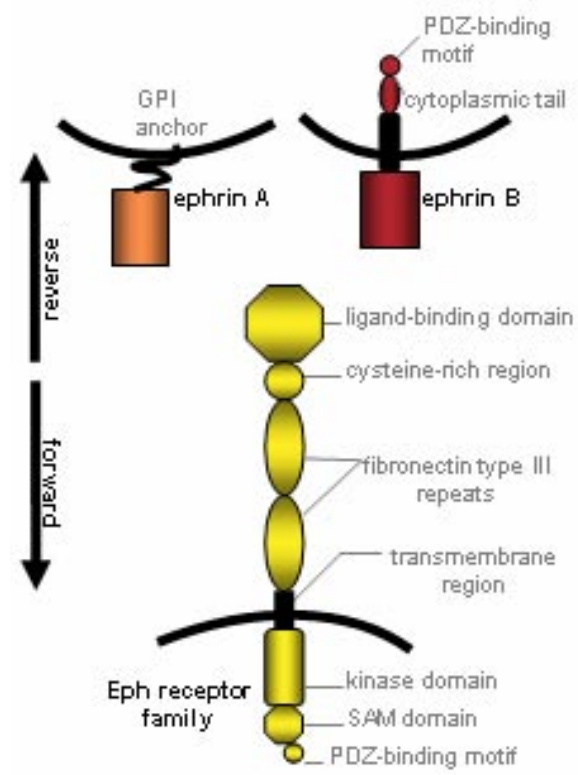

Fig. 1. Bi-directional signaling in the Eph receptor/ephrin communication system.

Eph receptors have been divided into an EphA subclass (8 members) and an EphB subclass (6 members) on the basis of sequence similarity and ligand affinity (Gale et. al., 1996). Ephrin ligands have also been divided into two subclasses: GPI-linked ephrin As (5 members) and transmembrane ephrin Bs (3 members). Although promiscuity has been observed, the ephrin A ligands preferentially bind to EphA receptors, while ephrin B ligands bind preferentially to EphB receptors (Heroult et. al., 2006).

The Eph receptor/ephrin system has been demonstrated to play a role in numerous biological processes. Generally, Ephs and ephrins are thought to act as graded molecular tags which translate the density of their cognate partner on opposing membranes into precisely graded cellular responses, resulting in cellcontact repulsion or cell-cell adhesion. Through this mechanism, the Eph receptor/ephrin system has been shown to direct the positioning, adhesion and migration of cells and cell layers during development (WimmerKleikamp and Lackmann, 2005). This system has also been implicated in immune regulation (Wu and Luo, 2005), as well as in central nervous system injury and disease (Goldshmit et. al., 2006). Recently, a role for the Eph receptor/ephrin system has also emerged in cancer, especially in the area of invasive behaviour.

\section{Eph Receptors and Ephrins in Cancer}

Though the majority of research has studied the Eph/ephrin role in development, new evidence suggests strong involvement in tumourigenesis, including metastasis, angiogenesis, and invasion (Dodolet and Pasquale, 2000; Wimmer-Kleikamp and Lackmann, 2005). Upon identification of EphA1, the first member of the Eph family, breast, liver, lung and colon tumours showed overexpression, but no evidence of gene amplification nor mutation (Hirai, et. al., 1987; Dodolet and Pasquale, 2000; Surawska et. al., 2004). Genes for other Eph receptors and ephrins have since been recognized to be overexpressed or differentially expressed in numerous human cancers (for review, see Surawska et. al., 2004). Mounting evidence documents a strong correlation between the expression levels of many Eph/ephrin family members and increased invasiveness of a number of aggressive tumours, including breast cancer, colon carcinoma, malignant melanoma, kidney carcinoma, ovarian cancer, neuroblastomas, and prostate cancer (WimmerKleikamp and Lackmann, 2005). It has also been suggested that elevated Eph/ephrin expression levels may be diagnostic for specific invasive, metastatic tumours and reduced patient survival rates (Saito et. al., 2004; Nakada et. al., 2006).

\section{Eph Receptors and Ephrins in Invasion}

For the purpose of this review, invasion is defined as "penetration of tissue barriers, such as basement membrane and interstitial stroma, by cells" (Friedl and Wolf, 2003). It occurs during normal cell morphogenesis, wound healing, and in malignant cells. Numerous Eph receptors and ephrins have been noted to influence or correlate with invasive behaviour. Cytotrophoblast commitment to uterine invasion, for example, was noted 
to be accompanied by upregulation of ephrin $\mathrm{B} 1$ and downregulation of EphB4 (Red-Horse et. al., 2005). Additionally, ephrin A5 expression was found to increase invasive behaviour, anchorage-independent growth, and morphological transformation of murine fibroblasts (Campbell et. al., 2006).The majority of research on Ephs and ephrins in invasion, however, has focused on their role in cancer (Table 1).

With respect to the EphA/ephrin A subsystem, Saito et. al. (2004) noted that expression level of EphA2 had a statistically significant relationship with liver metastasis, lymphatic vessel invasion, and clinical stage. Alford et. al. (2007) found that transglutaminase-cross-linked ephrin A1 and A5 bound to EphA receptors and promoted invasion and migration of HeLa cells. Moreover, lida et. al. (2005) reported that the poor prognosis of patients with AFP-producing hepatocellular carcinoma was partially caused by ephrin A1 expression, which induced expression of genes related to tumour cell growth, angiogenesis, invasion, and metastasis.

With respect to involvement of the EphB/ephrin B subsystem in invasion, a greater depth of investigation has occurred, resulting in both observational and mechanistic insight. Nakada et. al. (2004) demonstrated that EphB2-transfected glioma cells showed increased invasive behaviour both in vitro and in an ex vivo rat brain slice. Furthermore, glioma invasion was promoted by activation of EphB2 or inhibited by blocking EphB2. This invasive behaviour was revealed to be controlled through an EphB2/R-Ras signaling pathway (Nakada et. al., 2005).

EphB4 was shown to confer survival and invasive properties in head and neck squamous cell carcinoma (Masood et. al., 2006). Moreover, Alam et. al. (2007) reported that histoscores and mRNA levels of EphB4 and ephrin B2 significantly increased with clinical stages, dedifferentiation, and myometrial invasion in uterine endometrial cancer. Similarly, Takai et. al. (2004) noted that ephrin B2 and EphB4 expression were significantly associated with the presence of clinical stage, histological grade, and invasion to $>1 / 2$ myometrium in endometrial carcinomas. Currently, controversy surrounds the role of EphB4 in invasiveness and potential prognosis in breast cancer, since this receptor has been reported to act both as a tumour suppressor and a tumour promoter (Noren et. al., 2006; Noren and Pasquale, 2007).

Aside from the observations described in endometrial carcinomas, ephrin B2 mRNA expression was further reported to be elevated in higher stage neoplasms and in patients with high-risk AMES in malignant thyroid cancer (Kebebew et. al., 2005). Ephrin B2 was also visualized in the invasive front of malignant melanoma (Meyer et. al., 2005).

In the case of the correlation of ephrin B1 and B3 expression with invasive properties in cancer, mechanistic insight has also been provided. For ephrin $\mathrm{B} 1$, tyrosine phosphorylation of this ligand promoted invasion of gastric scirrhous carcinoma cells both in vitro and in vivo (Tanaka et. al., 2007a). Through the

Table 1. Invasive involvement of Eph receptors and ephrin ligands in cancer.

\begin{tabular}{|c|c|c|c|}
\hline $\begin{array}{l}\text { Ligand/ } \\
\text { Receptor }\end{array}$ & $\begin{array}{l}\text { Cell Line(s)/ } \\
\text { Tissue(s) }\end{array}$ & Observation(s) & Reference(s) \\
\hline ephrin A1 & $\begin{array}{l}\text { hepatocellular } \\
\text { carcinoma; HeLa cells }\end{array}$ & $\begin{array}{l}\text { poor prognosis of patients with AFP-producing hepatocellular carcinoma is } \\
\text { partially caused by ephrin A1 expression, which induces expression of genes } \\
\text { related to tumour cell growth, angiogenesis, invasion, and metastasis; } \\
\text { transglutaminase-cross-linked ephrin A1 and A5 bind to A-type Eph receptors } \\
\text { and promote invasion and migration of HeLa cells }\end{array}$ & $\begin{array}{l}\text { lida et. al., 2005; } \\
\text { Alford et. al., } 2007\end{array}$ \\
\hline ephrin A5 & HeLa cells & $\begin{array}{l}\text { transglutaminase-cross-linked ephrin A1 and A5 bind to A-type Eph receptors } \\
\text { and promote invasion and migration of HeLa cells }\end{array}$ & Alford et. al., 2007 \\
\hline ephrin B1 & $\begin{array}{l}\text { gastric scirrhous } \\
\text { carcinoma; pancreas } \\
\text { cancer cell lines }\end{array}$ & $\begin{array}{l}\text { tyrosine phosphorylation of ephrin B1 promotes invasion of cancer cells in } \\
\text { vitro and in vivo; expression of ephrin B1 promotes the invasion of cancer } \\
\text { cells in vivo, which requires the C-terminus of ephrin B1 }\end{array}$ & $\begin{array}{l}\text { Tanaka et. al., } \\
\text { 2007a; Tanaka et. } \\
\text { al., 2007b }\end{array}$ \\
\hline ephrin B2 & $\begin{array}{l}\text { endometrial } \\
\text { carcinoma; malignant } \\
\text { thyroid neoplasms; } \\
\text { malignant melanoma; } \\
\text { uterine endometrial } \\
\text { cancer }\end{array}$ & $\begin{array}{l}\text { ephrin B2 and EphB4 expression are significantly associated with the } \\
\text { presence of clinical stage, histological grade, and invasion to }>1 / 2 \\
\text { myometrium; ephrin B2 mRNA expression is elevated in higher TNM stage } \\
\text { neoplasms and in patients with high-risk AMES; prominent expression of } \\
\text { ephrin B2 is noted in the invasive front of malignant melanoma; histoscores } \\
\text { and mRNA levels of ephrinB2 and EphB4 significantly increase with clinical } \\
\text { stages, dedifferentiation and myometrial invasion }\end{array}$ & $\begin{array}{l}\text { Takai et. al., 2004; } \\
\text { Kebebew et. al., } \\
\text { 2005; Meyer et. } \\
\text { al., 2005; Alam et. } \\
\text { al., } 2007\end{array}$ \\
\hline ephrin B3 & $\begin{array}{l}\text { invasive glioma cells; } \\
\text { gliomas }\end{array}$ & $\begin{array}{l}\text { ephrin B3 is expressed in invasive glioma cells; ephrin B3 expression, } \\
\text { phosphorylation, and signaling through Rac1 are critically important to glioma } \\
\text { invasion }\end{array}$ & $\begin{array}{l}\text { Hoelzinger et. al., } \\
\text { 2005; Nakada et. } \\
\text { al., } 2006\end{array}$ \\
\hline EphA2 & colorectal cancer & $\begin{array}{l}\text { expression level of EphA2 has a statistically significant relationship with liver } \\
\text { metastasis, lymphatic vessel invasion and clinical stage }\end{array}$ & Saito et. al., 2004 \\
\hline EphB2 & $\begin{array}{l}\text { gliomas; glioma cells; } \\
\text { colorectal cancer }\end{array}$ & $\begin{array}{l}\text { U251 cells stably transfected with EphB2 show more pronounced invasive } \\
\text { growth in an ex vivo rat brain slice and glioma cell invasion is promoted by } \\
\text { activation of EphB2 or inhibited by blocking EphB2; EphB2/R-Ras signaling } \\
\text { regulates glioma cell adhesion, growth, and invasion; reduced expression of } \\
\text { EphB2 parallels invasion and metastasis in colorectal tumours }\end{array}$ & $\begin{array}{l}\text { Nakada et. al., } \\
\text { 2004; Nakada et. } \\
\text { al., } 2005 ; \text { Guo et. } \\
\text { al., } 2006\end{array}$ \\
\hline EphB4 & $\begin{array}{l}\text { endometrial } \\
\text { carcinoma; breast } \\
\text { cancer; head and } \\
\text { neck squamous cell } \\
\text { carcinoma; uterine } \\
\text { endometrial cancer }\end{array}$ & $\begin{array}{l}\text { ephrin B2 and EphB4 expression are significantly associated with the } \\
\text { presence of clinical stage, histological grade, and invasion to }>1 / 2 \\
\text { myometrium; EphB4 activates an antioncogenic Abl-Crk pathway that inhibits } \\
\text { breast cancer cell viability, proliferation, motility and invasion; histoscores and } \\
\text { mRNA levels of ephrinB2 and EphB4 significantly increase with clinical } \\
\text { stages, dedifferentiation and myometrial invasion; expression of EphB4 in } \\
\text { HNSCC tumor cells confers survival and invasive properties }\end{array}$ & $\begin{array}{l}\text { Takai et. al., 2004; } \\
\text { Noren et. al., } \\
\text { 2006; Masood et. } \\
\text { al., 2006; Alam et. } \\
\text { al., } 2007\end{array}$ \\
\hline EphB6 & breast cancer & $\begin{array}{l}\text { downregulation of EphB6 correlates with the most invasive aggressive cell } \\
\text { line and may serve as a prognostic indicator in breast cancer }\end{array}$ & $\begin{array}{l}\text { Fox and Kandpal, } \\
2004\end{array}$ \\
\hline
\end{tabular}


use of multiple cell lines, including pancreatic cancer cells, it was demonstrated that the C-terminus of ephrin B1 was responsible for conferring the increased invasive properties through activation of matrix metalloproteinase-8 secretion (Tanaka et. al., 2007b). For ephrin B3, increased expression was noted specifically in invasive glioma cells (Hoelzinger et. al., 2005), and this elevated ephrin B3 expression accompanied by phosphorylation leading to signaling through Rac1 was identified as critically important to glioma invasion (Nakada et. al., 2006).

It has been proposed that Ephs operate during tumour progression through uncontrolled re-emergence of their developmental cell guidance capacity, promoting tumour metastasis, invasion and neo-angiogenesis (Wimmer-Kleikamp and Lackmann, 2005). Interestingly, some studies have noted a down-regulation of Eph receptor expression corresponding to an invasive phenotype in certain cancers. For example, Fox and Kandpal (2004) reported that decreased expression of EphB6, which was down-regulated in the most aggressive breast cancer cell line, was particularly important in invasiveness. Additionally, Guo et. al. (2006) observed that reduced expression of EphB2 paralleled invasion and metastasis in colorectal tumours. Moreover, Batlle et. al. (2005) also noted that loss of EphB2 in colorectal cancer correlated with degree of malignancy. Thus, researchers have chosen to focus on individual Ephs and ephrins in specific types of cancer when designing potential therapies, instead of working from a general model.

\section{Therapeutic Implications}

Based upon the observed differential expression of Eph receptors and their ephrin ligands in a wide variety of cancers, it is not surprising that components of this system have been flagged as potential therapeutic targets. One approach has been antibody targeting of Ephs identified as consistently upregulated in specific cancers, thus offering selective targeting of tumour cells while minimizing harm to healthy tissues. This method has been used to target EphA2 in breast cancer cells (Carles-Kinch et. al., 2002) and EphB2 in colorectal cancer (Mao et. al., 2004).

Another approach is to use antagonistic peptides that display selective binding. This method has been used in the case of EphB2 (Chrencik et. al., 2007) and EphA2 (Koolpe et. al., 2002). Recently, Yamaguchi et. al. (2007) engineered a vaccine using dendritic cells pulsed with EphA2-derived peptides that resulted in long-term antitumour immunity against a rechallenge with MC38 tumour cells in a murine colon cancer model.

Function-blocking soluble Eph receptors have also been used to interfere with tumour growth and properties. As with the peptide approach, this method has been demonstrated for both the EphA and EphB subclasses (Brantley et. al., 2002; Martiny-Baron et. al., 2004; Kertesz et. al., 2006; Yang et. al., 2006). A recent encouraging result was reported by Dobrzanski et. al. (2004) who found that administration of EphA2/Fc profoundly inhibited the growth of primary tumours and the development of peritoneal, lymphatic, and hepatic metastases in a murine pancreatic ductal adenocarcinoma model. Interestingly, this approach was also employed from a ligand perspective by introducing soluble ephrin A1-Fc to suppress growth of EphA2-expressing gastric cancer cells (Nakamura et. al., 2005).

Eph/ephrin-influenced cytoskeletal signal transduction pathways dealing with cell motility, tumour invasiveness and metastatic potential have also been investigated as therapeutic targets. Such flagged components have included FAK, CRK, Rho, paxillin, Cbl, and Grb4 (Surawska et. al., 2004). Further understanding of the Eph/ephrin system will bring forth more candidate targets.

\section{Summary}

Due to the emergence of the Eph receptor/ephrin system as a contributor to cellular invasive behaviour, it is likely that this system will remain a high priority in oncology for the development of new therapies and treatments. For example, a currently underutilized approach is the use of RNA interference, the sequencespecific gene silencing induced by double-stranded RNA (Campbell and Choy, 2005). Numerous studies have utilized RNA interference to explore the effect of an Eph or ephrin knock-down in vitro, but have yet to engineer a successful in vivo method for the treatment of cancer.

Further studies in the manipulation of the Eph receptor/ephrin system will aid in engineering cancer therapies and in elucidating the complexity and additional functional implications of the system.

\section{Acknowledgements}

This work was supported by an operating grant from CIHR to S.M.R. S.M.R. currently holds a Canada Research Chair in Cancer Biology and is an Alberta Heritage Foundation for Medical Research (AHFMR) Scientist. T.N.C. was supported by AHFMR and Alberta Cancer Foundation Postdoctoral Fellowships.

\section{References}

Alam, S.M., Fujimoto, J., Jahan, I., Sato, E., and Tamaya, T. (2007). Overexpression of ephrinB2 and EphB4 in tumor advancement of uterine endometrial cancers. Ann. Oncol. $18,485-490$.

Alford, S.C., Bazowski, J., Lorimer, H., Elowe, S., and Howard, P.L. (2007). Tissue transglutaminase clusters soluble A-type ephrins into functionally active high molecular weight oligomers. Exp. Cell. Res. 313, 41704179.

Batlle, E., Bacani, J., Begthel, H., Jonkeer, S., Gregorieff, A., van de Born, M., Malats, N., Sancho, E., Boon, E., Pawson, T., Gallinger, S., Pals, S., and Clevers, H. (2005). EphB receptor activity suppresses colorectal cancer progression. Nature 435, 1126-1130.

Brantley, D.M., Cheng, N., Thompson, E.J., Lin, Q., Brekken, R.A., Thorpe, P.E., Muraoka, R.S., Cerretti, D.P., Pozzi, A., Jackson, D., Lin, C., and Chen, J. 
(2002). Soluble Eph A receptors inhibit tumor angiogenesis and progression in vivo. Oncogene 21, 7011-7026.

Campbell, T.N., Attwell, S., Arcellana-Panlilio, M., and Robbins, S.M. (2006). Ephrin A5 expression promotes invasion and transformation of murine fibroblasts. Biochem. Biophys. Res. Comm. 350, 623-628.

Campbell, T.N. and Choy, F.Y.M. (2005). RNA interference: past, present and future. Curr. Issues Mol. Biol. 7, 1-6.

Carles-Kinch, K., Kilpatrick, K.E., Stewart, J.C., and Kinch, M.S. (2002). Antibody targeting of the EphA2 tyrosine kinase inhibits malignant cell behaviour. Cancer Res. 62, 2840-2847.

Chrencik, J.E., Brooun, A., Recht, M.I., Nicola, G., Davis, L.K., Abagyan, R., Widmer, H., Pasquale, E.B., and Kuhn, P. (2007). Three-dimensional structure of the EphB2 receptor in complex with an antagonistic peptide reveals a novel mode of inhibition. J Biol. Chem. 282, 36505-36513.

Dobrzanski, P., Hunter, K., Jones-Bolin, S., Chang, H., Robinson, C., Pritchard, S., Zhao, H., and Ruggeri, B. (2004). Antiangiogenic and antitumor efficacy of EphA2 receptor antagonist. Cancer Res. 64, 910-919.

Dodelet, V.C. and Pasquale, E.B. (2000). Eph receptors and ephrin ligands: embryogenesis to tumourigenesis. Oncogene 19, 5614-5619.

Fox, B.P. and Kandpal, R.P. (2004). Invasiveness of breast carcinoma cells and transcript profile: Eph receptors and ephrin ligands as molecular markers of potential diagnostic and prognostic application. Biochem. Biophys. Res. Comm. 318, 882-892.

Friedl, P. and Wolf, K. (2003). Tumour-cell invasion and migration: diversity and escape mechanisms. Nat. Rev. Cancer 3, 362-374.

Gale, N.W., Holland, S.J., Valenzuela, D.M., Flenniken, A., Pan, L., Ryan, T.E., Henkemeyer, M., Strebhardt, K., Hirai, H., Wilkinson, D.G., Pawson, T., Davis, S., and Yancopoulos, G.D. (1996). Eph receptors and ligands comprise two major specificity subclasses and are reciprocally compartmentalized during embryogenesis. Neuron 17, 9-19.

Goldshmit, Y., McLenachan, S., and Turnley, A. (2006). Roles of Eph receptors and ephrins in the normal and damaged adult CNS. Brain Res. Rev. 52, 327-345.

Guo, D.L., Zhang, J., Yuen, S.T., Tsui, W.Y., Chan, A.S., Ho, C., Ji, J., Leung, S.Y., and Chen, X. (2006). Reduced expression of EphB2 that parallels invasion and metastasis in colorectal tumours. Carcinogenesis 27, 454-464.

Heroult, M., Schaffner, F., and Augustin, H.G. (2006). Eph receptor and ephrin ligand-mediated interactions during angiogenesis and tumour progression. Exper. Cell Res. 312, 642-650.

Hirai, H., Maru, Y., Hagiwara, K., Nishida, J., and Takaku, F. (1987). A novel putative tyrosine kinase receptor encoded by the eph gene. Science 238,1717 1720.

Hoelzinger, D.B., Mariani, L., Weis, J., Woyke, T., Berens, T.J., McDonough, W.S., Sloan, A., Coons, S.W., and Berens, M.E. (2005). Gene expression profile of glioblastoma multiforme invasive phenotype points to new therapeutic targets. Neoplasia 7, 7-16.

lida, H., Honda, M., Kawai, H.F., Yamashita, T., Shirota, Y., Wang, B.C., Miao, H., and Kaneko, S. (2005). Ephrin-A1 expression contributes to the malignant characteristics of \{alpha\}-fetoprotein producing hepatocellular carcinoma. Gut 54, 843-851.

Kebebew, E., Peng, M., Reiff, E., Duh, Q.Y., Clark, O.H., and McMillan, A. (2005). Diagnostic and prognostic value of angiogenesis-modulating genes in malignant thyroid neoplasms. Surgery $138,1102-1109$.

Kertesz, N., Krasnoperov, V., Reddy, R., Leshanski, L., Kumar, S.R., Zozulya, S., and Gill, P.S. (2006). The soluble extracellular domain of EphB4 (sEphB4) antagonizes EphB4-EphrinB2 interaction, modulates angiogenesis, and inhibits tumor growth. Blood 107, 2330-2338.

Koolpe, M., Dail, M., and Pasquale, E.B. (2002). An ephrin mimetic peptide that selectively targets the EphA2 receptor. J. Biol. Chem. 277, 46974-46979.

Kullander, K. and Klein, R., (2002). Mechanisms and functions of Eph and ephrin signaling. Nat. Rev. Mol. Cell. Biol. 3, 475-486.

Mao, W., Luis, E., Ross, S., Silva, J., Tan, C., Crowley, C., Chui, C., Franz, G., Senter, P., Koeppen, H., and Polakis, P. (2004). EphB2 as a therapeutic antibody drug target for the treatment of colorectal cancer. Cancer Res. 64, 781-788.

Martiny-Baron, G., Korff, T., Schaffner, F., Esser, N., Eggstein, S., Marme, D., and Augustin, H.G. (2004). Inhibition of tumour growth and angiogenesis by soluble EphB4. Neoplasia 6, 248-257.

Meyer, S., Hafner, C., Guba, M., Flegel, S., Geissler, E.K., Becker, B., Koehl, G.E., Orso, E., Landthaler, M., and Vogt, T. (2005). Ephrin-B2 overexpression enhances integrin-mediated ECM-attachment and migration of B16 melanoma cells. Int. J. Oncol. 27, 1197-1206.

Masood, R., Kumar, S.R., Sinha, U.K., Crowe, D.L., Krasnoperov, V., Reddy, R.K., Zozulya, S., Singh, J., Xia, G., Broek, D., Schönthal, A.H., and Gill, P.S. (2006). EphB4 provides survival advantage to squamous cell carcinoma of the head and neck. Int. J. Cancer 119, 1236-1248. 
Nakada, M., Drake, K.L., Niska, J.A., and Berens, M.E. (2006). Ephrin-B3 ligand promotes glioma invasion through activation of Rac1. Cancer Res. 66, 8492-8500.

Nakada, M., Niska, J.A., Miyamori, H., McDonough, W.S., Wu, J., Sato, H., and Berens, M.E. (2004). The phosphorylation of EphB2 receptor regulates migration and invasion of human glioma cells. Cancer Res. 64, 3179-3185.

Nakada, M., Niska, J.A., Tran, N.L., McDonough, W.S., and Berens, M.E. (2005). EphB2/R-Ras signaling regulates glioma cell adhesion, growth, and invasion. Am. J. Pathol. 167, 565-576.

Noren, N.K., Foos, G., Hauser, C.A., and Pasquale, E.B. (2006). The EphB4 receptor suppresses breast cancer cell tumorigenicity through an Abl-Crk pathway. Nat. Cell. Biol.8, 815-825.

Noren, N.K. and Pasquale, E.B. (2007). Paradoxes of the EphB4 receptor in cancer. Cancer Res. 67, 39943997.

Red-Horse, K., Kapidzic, M., Zhou, Y., Feng, K.T., Singh, H., and Fisher, S.J. (2005). EPHB4 regulates chemokine-evoked trophoblast responses: a mechanism for incorporating the human placenta into the maternal circulation. Development 132, 4097-4106.

Saito, T., Masuda, N., Miyazaki, T., Kanoh, K., Suzuki, H., Shimura, T., Asao, T., and Kuwano, H. (2004). Expression of EphA2 and E-cadherin in colorectal cancer: correlation with cancer metastasis. Oncol. Rep. $11,605-611$.

Surawska, H., Ma, P.C., and Salgia, R. (2004). The role of ephrins and Eph receptors in cancer. Cytokine Growth Factor Rev. 15, 419-433.

Takai, N., Ueda, T., Nishida, M., Nasu, K., and Miyakawa, I. (2004). The relationship between oncogene expression and clinical outcome in endometrial carcinoma. Curr. Cancer Drug Targets 4, 511-520.

Tanaka, M., Kamata, R., Takigahira, M., Yanagihara, K., and Sakai, R. (2007a). Phosphorylation of ephrin-B1 regulates dissemination of gastric scirrhous carcinoma. Am. J. Pathol. 171, 68-78.

Tanaka, M., Sasaki, K., Kamata, R., and Sakai, R. (2007b). The C-terminus of ephrin-B1 regulates metalloproteinase secretion and invasion of cancer cells. J. Cell. Sci. 120, 2179-2189.

Wimmer-Kleikamp, S.H. and Lackmann, M. (2005). Eph-modulated cell morphology, adhesion and motility in carcinogenesis. IUBMB Life 57, 421-431.

Wu, J. and Luo, H. (2005). Recent advances on T-cell regulation by receptor tyrosine kinases. Curr. Opin. Hematol. 12, 292-297.
Yamaguchi, S., Tatsumi, T., Takehara, T., Sakamori, R., Uemura, A., Mizushima, T., Ohkawa, K., Storkus, W.J., and Hayashi, N. (2007). Immunotherapy of murine colon cancer using receptor tyrosine kinase EphA2-derived peptide-pulsed dendritic cell vaccines. Cancer 110, 1469-1477.

Yang, N.Y., Pasquale, E.B., Owen, L.B., and Ethell, I.M. (2006). The EphB4 receptor-tyrosine kinase promotes the migration of melanoma cells through Rho-mediated actin cytoskeleton reorganization. J. Biol. Chem. 281, 32574-32586. 


\section{Further Reading}

Caister Academic Press is a leading academic publisher of advanced texts in microbiology, molecular biology and medical research. Full details of all our publications at caister.com

- MALDI-TOF Mass Spectrometry in Microbiology Edited by: M Kostrzewa, S Schubert (2016) www.caister.com/malditof

- Aspergillus and Penicillium in the Post-genomic Era Edited by: RP Vries, IB Gelber, MR Andersen (2016) www.caister.com/aspergillus2

- The Bacteriocins: Current Knowledge and Future Prospects Edited by: RL Dorit, SM Roy, MA Riley (2016)

www.caister.com/bacteriocins

- Omics in Plant Disease Resistance Edited by: V Bhadauria (2016) www.caister.com/opd

- Acidophiles: Life in Extremely Acidic Environments Edited by: R Quatrini, DB Johnson (2016) www.caister.com/acidophiles

- Climate Change and Microbial Ecology: Current Research and Future Trend

Edited by: J Marxsen (2016)

www.caister.com/climate

- Biofilms in Bioremediation: Current Research and Emerging Technologies

Edited by: G Lear (2016)

www.caister.com/biorem

- Microalgae: Current Research and Applications Edited by: MN Tsaloglou (2016) www.caister.com/microalgae

- Gas Plasma Sterilization in Microbiology: Theory, Applications, Pitfalls and New Perspectives Edited by: H Shintani, A Sakudo (2016) www.caister.com/gasplasma

- Virus Evolution: Current Research and Future Directions Edited by: SC Weaver, M Denison, M Roossinck, et al. (2016) www.caister.com/virusevol

- Arboviruses: Molecular Biology, Evolution and Control Edited by: N Vasilakis, DJ Gubler (2016) www.caister.com/arbo

- Shigella: Molecular and Cellular Biology Edited by: WD Picking, WL Picking (2016) www.caister.com/shigella

-Aquatic Biofilms: Ecology, Water Quality and Wastewater Treatment

Edited by: AM Romaní, H Guasch, MD Balaguer (2016)

www.caister.com/aquaticbiofilms

- Alphaviruses: Current Biology

Edited by: S Mahalingam, L Herrero, B Herring (2016)

www.caister.com/alpha

- Thermophilic Microorganisms

Edited by: F Li (2015)

www.caister.com/thermophile
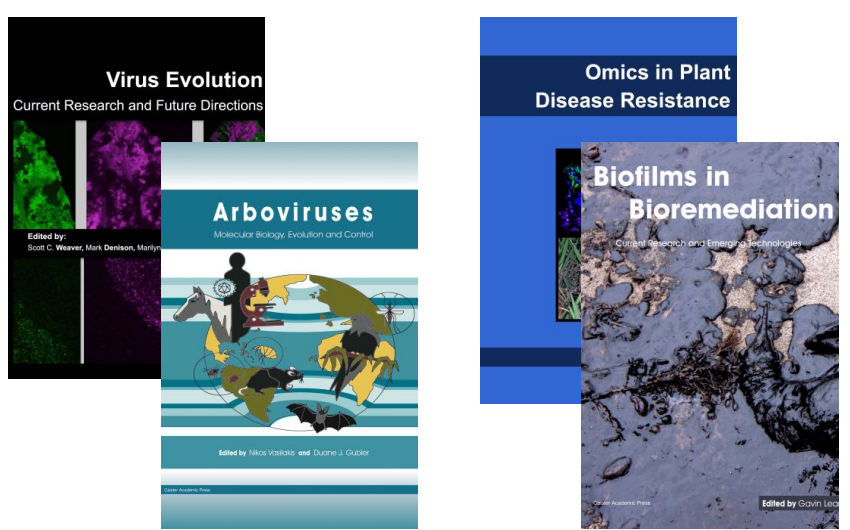
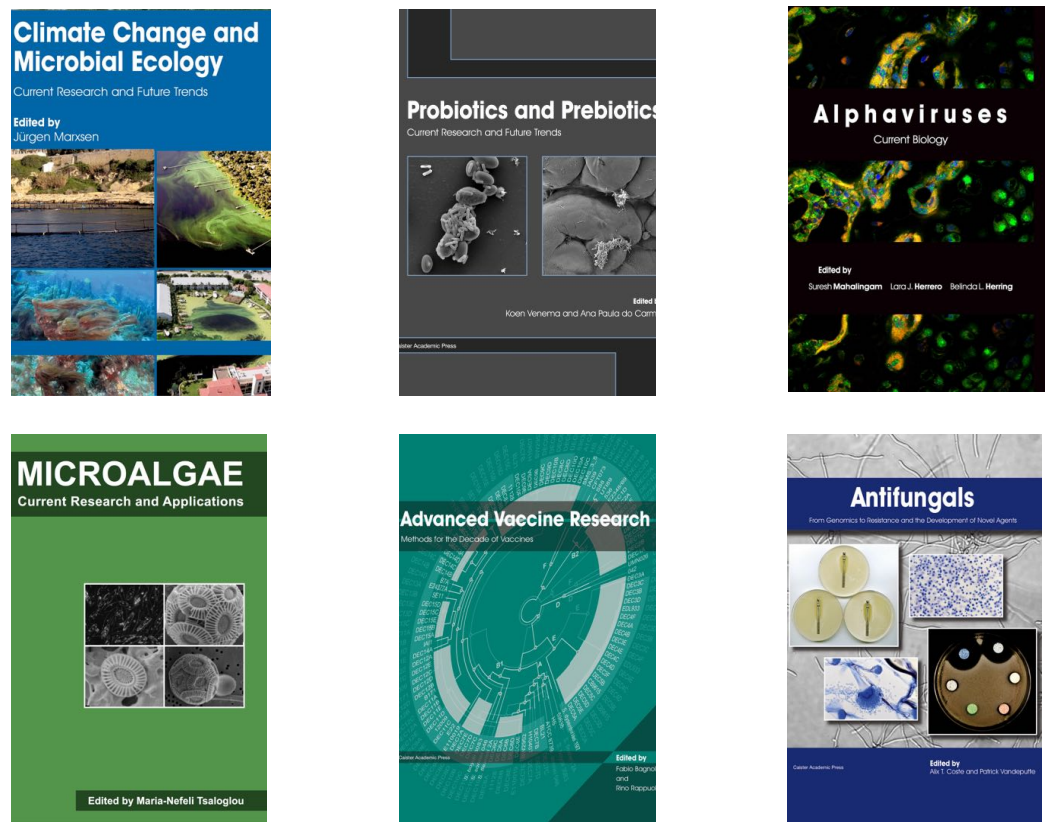

- Flow Cytometry in Microbiology: Technology and Applications Edited by: MG Wilkinson (2015) www.caister.com/flow

- Probiotics and Prebiotics: Current Research and Future Trends Edited by: K Venema, AP Carmo (2015) www.caister.com/probiotics

- Epigenetics: Current Research and Emerging Trends Edited by: BP Chadwick (2015) www.caister.com/epigenetics2015

- Corynebacterium glutamicum: From Systems Biology to Biotechnological Applications

Edited by: A Burkovski (2015)

www.caister.com/cory2

- Advanced Vaccine Research Methods for the Decade of Vaccines

Edited by: F Bagnoli, R Rappuoli (2015)

www.caister.com/vaccines

- Antifungals: From Genomics to Resistance and the Development of Novel Agents

Edited by: AT Coste, P Vandeputte (2015)

www.caister.com/antifungals

- Bacteria-Plant Interactions: Advanced Research and Future Trends Edited by: J Murillo, BA Vinatzer, RW Jackson, et al. (2015) www.caister.com/bacteria-plant

\section{- Aeromonas}

Edited by: J Graf (2015)

www.caister.com/aeromonas

- Antibiotics: Current Innovations and Future Trends

Edited by: S Sánchez, AL Demain (2015)

www.caister.com/antibiotics

- Leishmania: Current Biology and Contro Edited by: S Adak, R Datta (2015) www.caister.com/leish2

- Acanthamoeba: Biology and Pathogenesis (2nd edition) Author: NA Khan (2015)

www.caister.com/acanthamoeba2

- Microarrays: Current Technology, Innovations and Applications Edited by: Z He (2014)

www.caister.com/microarrays2

- Metagenomics of the Microbial Nitrogen Cycle: Theory, Methods and Applications

Edited by: D Marco (2014)

www.caister.com/n2 